\title{
Liver Transplantation in Patients with Hepatocellular Carcinoma
}

\author{
Gi-Won Song, M.D., Shin Hwang, M.D., and Sung-Gyu Lee, M.D. \\ Department of Surgery, Division of Liver Transplantation and Hepatobiliary Surgery, \\ Asan Medical Center, University of Ulsan College of Medicine, Seoul, Korea
}

Hepatocellular carcinoma (HCC) is the third most common malignancy, with a new incidence of more than 11,000 cases per year and the second most common cause of malignancy-related death in Korean males. In Korea, more than $80 \%$ of all HCCs have developed from hepatitis B virus (HBV)-related cirrhotic livers. Liver transplantation (LT) is the only treatment that offers a chance of cure for HCC and the underlying liver cirrhosis simultaneously, but the availability of liver grafts and the aggressiveness of tumor recurrence are critical limiting factors of LT for HCC patients. The serious shortage of deceased-donors on strong demand for LT leads to the development of living-donor LT (LDLT) as a practical alternative replacing deceased-donor LT. Considering that HCC recurrence is the most common cause of posttransplant patient death, recipient candidates should be prudently selected through objectively established criteria. Uniquely, some Asian major LDLT centers challenged the Milan criteria, accepting a much higher number of HCC nodules instead of tumor size expansion. The eligibility criteria of LDLT for HCC are likely to be expanded more than before, but it still requires further qualified risk-benefit analyses. The development of new effective treatment modalities for HCC recurrence will reasonably expand the selection criteria further wide without the expense of recurrence rate. This article is mainly focused on the role of LT for HCC and discussed on the validity of currently available indication criteria. (Korean $\mathbf{J}$ Gastroenterol 2010;55:350-360)

Key Words: Hepatocellular carcinoma; Liver transplantation; Indication criteria

\section{서 론}

간세포암의 가장 효과적인 치료는 수술적 절제로 알려져 있으나, 병소의 개수, 위치 및 기저 간기능 등의 장애 요인 으로 인해 수술적 절제의 적용이 불가능한 경우가 많다. 특 히 B형 또는 C형 간염 등과 같이 바이러스성 간염과 연관

\footnotetext{
연락처: 이승규, 138-736, 서울시 송파구 풍납2동 아산병 원길 388-1

서울아산병원 외과

Tel: (02) 3010-3485, Fax: (02) 474-9027

E-mail: sglee2@amc.seoul.kr
}

된 간세포암의 경우 동반된 간경화 때문에 기능적 간예비능 이 저하되어 간세포암 진단 당시에 약 $20 \%$ 의 환자에서만이 수술적 절제가 가능한 것으로 보고되고 있다. 따라서 B형 간염의 유병률이 높은 한국에서는 $80 \%$ 이상의 간세포암이 $\mathrm{B}$ 형 간염과 관련하여 발생하고 있으며, 간경변을 동반하고 있는 경우가 많아 수술적 치료의 장애 요인으로 되고 있다.

Correspondence to: Sung-Gyu Lee, M.D.

Department of Surgery, Asan Medical Center, 388-1, Asanbyungwongil, Pungnap 2-dong, Songpa-gu, Seoul 138-736, Korea Tel: +82-2-3010-3485, Fax: +82-2-474-9027

E-mail: sglee2@amc.seoul.kr 
따라서 B형 간염 간경변 및 간세포암에 이환된 환자의 간 을 완전히 제거하고 건강한 공여자의 간을 이식하는 간이식 은 간세포암의 완전 제거 및 기저 간경변의 치료를 동시에 달성할 수 있다는 측면에서 가장 효과적인 치료법이 될 수 있다. 그러나 간세포암에 대한 간이식의 초기 경험에서는 그 결과가 그리 만족스럽지 못하여 1990년대 중반까지는 약 $60-80 \%$ 의 높은 재발률과 $20-30 \%$ 의 3 년생존율이 보고되었 다. ${ }^{1-3}$ 이런 불량한 결과는 대상자 선정에 있어 적절한 기준 이 없이 무분별하게 간세포암의 진전 병기를 감안하지 않고 서 간이식을 시행했기 때문으로 추정된다. 이후 만족할 만 한 치료성적을 기대할 수 있는 대상자 선정 기준에 대한 여 러 연구 결과들이 보고되고 있다. 그 중 이탈리아 Milan 그 룹은 간이식 전 간외전이 또는 혈관침습이 없고, 직경이 5 $\mathrm{cm}$ 이하인 단일 결절, 또는 개수가 3 개 이하이면서 각 결절 의 직경이 $3 \mathrm{~cm}$ 이하인 다발성 결절을 가진 환자군에서 간 이식 후 4년 누적생존율 $75 \%$ 및 무병생존율 $83 \%$ 라는 매우 우수한 성적을 보고하였다. ${ }^{4}$ 이는 'Milan기준'으로 명명되어 이후 대부분의 이식센터에서 간세포암의 간이식에 있어 대 상자 선정기준의 표준 기준으로 사용되고 있고, 뇌사자 간 이식에 있어 장기 할당 시의 정책적 기준으로도 이용되고 있다. 그러나 Milan기준은 간이식 시 뇌사자가 기증한 장기 를 사회적 자원으로 보고서 장기이용 효율을 최대화하기 위 한 목적으로 사용되어 왔기 때문에, 좀더 진행된 간세포암 환자에서는 치료 혜택이 제한된다는 비판을 받아왔다. 더욱 이 뇌사자 간이식과는 달리 생체 간이식에서는 공여장기가 가족 간의 유대에 따른 기증이기 때문에 사회적 공유라는 개념의 적용을 받지 않고, 기증자 안전을 담보한다는 전제 하에서는 기증의 제한이 없기 때문에 Milan기준보다는 좀더 완화된 선정 기준을 적용이 적용되고 있다(Table 1). 그러나 생체 간이식의 경우 필연적으로 건강한 기증자의 수술 위험 을 수반하게 되며, 이 위험 부담은 수혜자에 있어 만족할 만 한 치료 성적을 확보할 수 있을 때만이 정당화될 수 있다는 윤리적 측면이 반드시 고려되어야 한다. 따라서 간세포암에
대한 생체간이식의 적용에 있어 확대된 대상자 선정기준에 대해 아직도 비판적 의견이 있고 이식센터 간 통일된 적용 기준이 아직 없는 실정이다.

이 논문에서는 서울아산병원에서 시행된 생체간이식의 결과를 중심으로 간세포암의 치료에 있어 간이식의 역할을 살펴보고, Milan기준보다 확대된 적용기준과 그 적용 결과 들을 알아보고자 한다.

\section{간세포암에서 간이식의 역할}

대부분의 간세포암은 만성 간질환과 연관되어 발생한다. 간절제술, 경동맥화학색전술 및 고주파열응고술 등과 같은 국소치료법의 효과가 이전에 비해 현저히 향상된 것은 사실 이지만, 여전히 높은 재발률과 불량한 잔존 간기능으로 인 하여 이러한 치료법의 적용에 한계가 있다. 또한 높은 재발 률의 주요 요인으로는 만성 간질환에 이환된 환자의 간이 전암 병소와 같은 역할을 하기 때문으로 여겨지고 있으므로 암종의 완전한 제거 및 전암 병소인 잔존 간을 완전히 새로 운 간으로 바꾸는 간이식은 매력적인 간세포암의 치료법이 라고 할 수 있다. 그러나 어느 단계 이상으로 진행된 간세포 암의 경우 더 이상 국소 질환이 아니라는 점과 간이식 후 필연적으로 사용해야 하는 면역억제제가 숙주의 신생물 발 생에 대한 감시능력을 저하시킨다는 점 때문에 간이식 후 간세포암의 높은 재발률에 대한 우려가 있어왔다. 또한 뇌 사자간이식의 경우 뇌사공여자의 절대부족, 생체간이식에서 는 기증자 안전 확보라는 문제가 수반되기 때문에 간세포암 환자에서의 간이식은 매우 제한적으로 시행되어오고 있다. 그러나 간세포암의 생물학적 특성에 대한 이해의 향상과 각 종 영상 진단장비의 발달은 간세포암 환자를 보다 선별하여 간이식 수술을 받게 해주고 있고, 따라서 보다 향상된 결과 를 보이게 되었다. 특히 우리나라를 포함한 아시아 지역의 국가에서는 불량한 잔존 간기능으로 인해 수술적 절제 및 고 식적 치료법을 적용할 수 없는 간세포암 환자에서 보다 확대

Table 1. Eligibility Criteria of Liver Transplantation for Hepatocellular Carcinoma

\begin{tabular}{|c|c|}
\hline Institution & Selection criteria \\
\hline Milan University, Italy $^{4}$ & Single, $\phi \leq 5 \mathrm{~cm}$; or 2 to $3, \operatorname{Max} \phi \leq 3 \mathrm{~cm}$ \\
\hline UCSF University, USA $^{5}$ & Single, $\phi \leq 6.5 \mathrm{~cm}$; or 2 to 3 , Max $\phi \leq 4.5 \mathrm{~cm}$, Sum $\phi \leq 8 \mathrm{~cm}$ \\
\hline Asan Medical Center, Korea ${ }^{6}$ & Max $\phi \leq 5 \mathrm{~cm}$, number $\leq 6$, no gross vascular invasion \\
\hline Samsung Medical Center, Korea ${ }^{7}$ & Max $\phi \leq 5 \mathrm{~cm}$, any number, AFP $\leq 400 \mathrm{ng} / \mathrm{dL}$ \\
\hline Seoul University Hospital, Korea ${ }^{8}$ & Max $\phi \leq 5 \mathrm{~cm}$, number $\leq 10$, PIVKA-II $\leq 400 \mathrm{mAU} / \mathrm{mL}$ \\
\hline Kyoto University, Japan ${ }^{9}$ & Max $\phi \leq 5 \mathrm{~cm}$, number $\leq 10$, PIVKA-II $\leq 400 \mathrm{mAU} / \mathrm{mL}$ \\
\hline Tokyo University, Japan ${ }^{10}$ & Max $\phi \leq 5 \mathrm{~cm}$, number $\leq 5$ \\
\hline Kyushu University, Japan ${ }^{11}$ & Max $\phi \leq 5 \mathrm{~cm}$, any number, DCP $\leq 300 \mathrm{ng} / \mathrm{dL}$ \\
\hline
\end{tabular}

AFP, alpha-fetoprotein; DCP, des-gamma-carboxy prothrombin; PIVKA-II, protein induced by vitamin $\mathrm{K}$ absence or antagonist-II. 


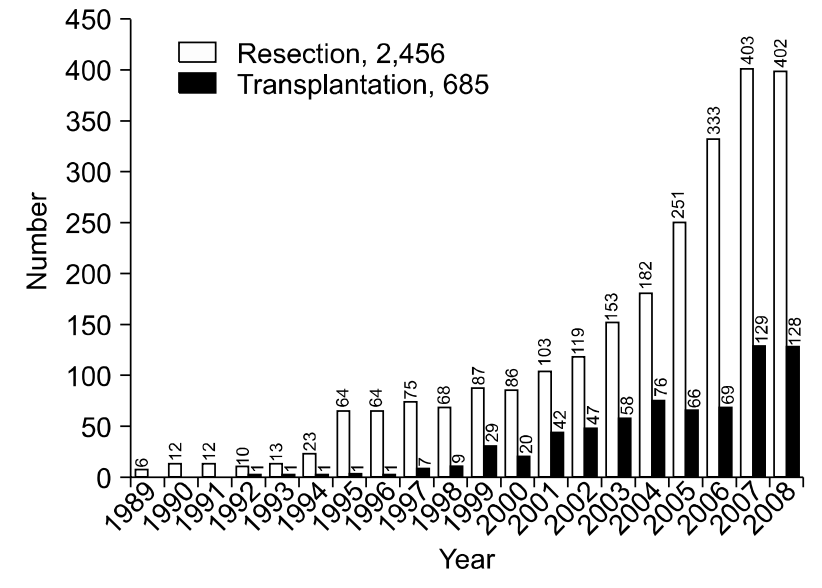

Fig. 1. Liver resection and transplantation for hepatocellular carcinoma at Asan Medical Center from June 1989 to December 2008.

된 적용 기준을 가지고 생체간이식을 시행하고 있다. ${ }^{5-11}$

1989년 6월부터 2008년 12월까지 서울아산병원 외과에서 는 간세포암에 대해 2,456 예의 수술적 절제와 685 예의 간이 식을 시행했다(Fig. 1). 간세포암의 치료에 있어서 여전히 수 술적 절제를 우선적으로 고려하고 있으나, 국내 특성상 B형 간염과 관련된 간세포암의 빈도가 압도적으로 높아 간세포 암으로 진단된 환자들의 절제 가능성은 상대적으로 낮다. 따라서 기저 간예비능의 저하로 인한 절제 불가능은 간이식 수술이 필수적으로 필요하게 만들었고, 저자들이 1997년 간 세포암에 대한 생체간이식을 첫 시행한 이후 간세포암 환자 에서의 생체간이식의 숫자가 지속적으로 증가하였다. ${ }^{12} 1992$ 년 8월부터 2008년 4월까지 총 1,806 예의 성인 간이식이 시 행되었고, 그 중 1,575예(87.2\%)가 생체 간이식이었고, 231 예(12.8\%)는 뇌사자 간이식이었다. 성인 생체 간이식 1,575 예 중 간세포암을 동반한 경우가 553예로 $35.1 \%$ 를 차지했 으며, 뇌사자 간이식 231예에서는 52예로 $22.5 \%$ 를 차지했 다. 성인 생체간이식에 있어 간세포암이 차지하는 빈도는 최근 점점 증가하고 있는 추세이며, 2007년의 경우 전체 환 자의 $43.8 \%$ 가 간세포암을 동반하고 있었다(Fig. 2). 이렇게 간세포암에 대한 간이식의 비중이 점차적으로 높아지는 이 유는 간세포암에 대한 간이식의 경험이 쌓이면서 각각의 간 이식센터에서 장단기적으로 만족할 만한 치료 성적을 보이 고 있기 때문이다. 또한 생체간이식을 중심으로 수술기법의 개선, 면역억제제의 개발 및 수술 후 집중치료법의 향상으 로 인한 간이식의 수술 후 사망률이 현저히 감소되고, 보험 적용 확대로 인하여 간이식의 비용적 부담이 현저히 줄어든 것도 그 원인으로 추정된다. ${ }^{13}$ 불량한 잔존 간기능으로 인해 비수술적 치료법을 선택해왔던 소간세포암 환자나 수술적 절제를 우선적으로 고려해 왔던 잔존 간기능이 어느 정도 보존된 환자에 대해 이전보다 의료진이나 환자 측 모두 간

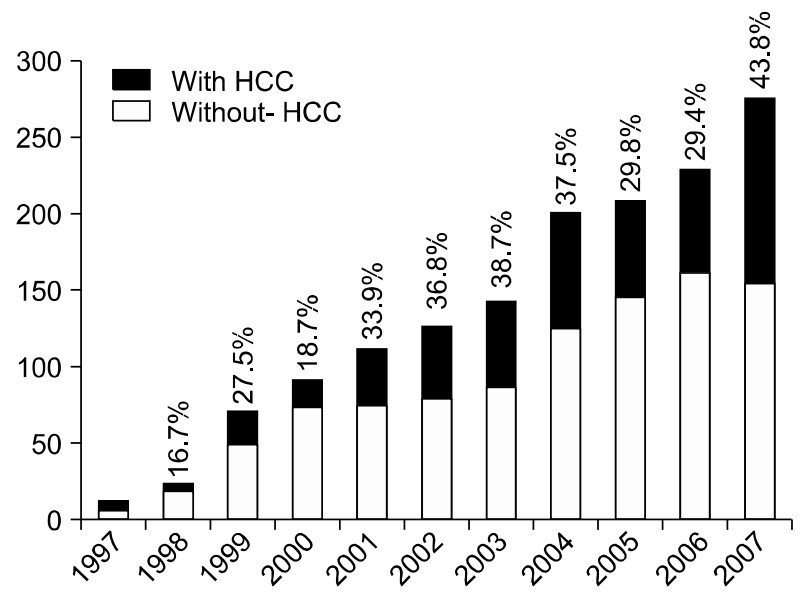

Fig. 2. Annual changes in the proportion of hepatocellular carcinoma patients in adult living-donor liver transplantation at Asan Medical Center.

이식을 보다 적극적으로 고려하기 때문인 것으로 추정된 다. ${ }^{14}$

\section{간세포암의 치료에 있어 생체 간이식과 뇌사자 간이식의 비교}

우리나라를 비롯한 아시아 지역의 대부분 국가에서는 뇌 사 공여자의 절대적 부족으로 인해 간세포암에 대해 뇌사자 간이식을 시행하기 위해서는 상당한 대기 시간을 감수해야 하며 부족한 공여장기가 대부분 응급도가 높은 환자들에게 할당되고 있는 상황을 고려하면 현실성이 거의 없는 치료법 이라고 할 수 있다.

미국에서 Gondolesi 등 ${ }^{15}$ 은 이식 대기기간이 뇌사자간이식 은 평균 459일, 생체간이식은 평균 62 일로 보고했고, 홍콩에 서 Lo 등 ${ }^{16}$ 도 각각 344 일과 24 일로 현격한 차이가 있는 것으 로 보고하였다. 따라서 뇌사자간이식에서는 상대적으로 긴 이식 전 대기기간으로 인한 간세포암의 진행과 이로 인한 중도 탈락의 예가 상대적으로 많을 수밖에 없다. 따라서 짧 은 대기기간이라는 측면에서 생체간이식이 간세포암의 치 료에 있어 상당한 이점을 가진다고 평가할 수 있깄으나, 몇 몇 그룹에서는 생체간이식이 오히려 이식 후 재발률을 높일 수 있는 요인들을 가지고 있어서 뇌사자간이식에 비해 불량 한 예후를 보일 수 있다고 주장하였다. ${ }^{17}$ Hiatt 등 ${ }^{18}$ 은 생체 간이식의 경우 짧은 대기 기간으로 인해 간세포암의 생물학 적 특성을 파악할 충분한 관찰 기간을 가지지 못하고 수술 을 시행함으로써 생물학적 특성이 나쁜 간세포암에서 간이 식을 시행할 가능성이 높다는 점을 지적했다. 또한 생체 간 이식에서는 공여간의 해부학적 특성으로 인해 수혜자 측의 혈관 및 담도를 충분히 남겨야 한다는 점도 종양학적인 측 
면에서는 이론적으로는 불리한 요소가 될 수 있다. 또한 이 식 직후 공여간의 왕성한 재생과 관련한 신생혈관생성 촉진 효과가 간세포암의 재발 및 침습도와 관련이 있기 때문에 국소재발 및 원격전이의 위험이 과소이식편(small-for-size graft)을 이용한 생체 간이식에서 더 높다는 보고도 있다. ${ }^{19,20}$

그러나 실제 임상결과에 있어서는 간세포암에 대한 뇌사 자간이식과 생체간이식은 무병생존율 및 환자생존율에 있 어 유사한 결과를 보여주고 있다. 한국과 일본의 다기관을 대상으로 한 대규모의 후향 연구에서는 UCSF기준을 적용 한 생체간이식의 성적이 뇌사자간이식과 동등한 결과를 보 였다. ${ }^{21,22}$ 또한 국내 4개소의 간이식센터를 대상으로 1992년 8 월부터 2002년 12월까지 간세포암으로 간이식을 시행받은 312 명의 치료 결과를 분석한 결과 생체간이식의 3 년생존율 이 $73.2 \%$ 로 뇌사자간이식 시의 $61.3 \%$ 에 비해 오히려 더 양 호한 결과를 보였다(Table 2). 38명의 원내사망 예와 39명의 간절제 표본에서 우연히 발견된 간세포암을 제외한 생존분 석에서는 2년 무병생존율이 뇌사자간이식과 생체간이식에 서 각각 $81.6 \%$ 와 $79.9 \%$ 로 통계적으로 유의한 차이를 보이 지 않았다 $(\mathrm{p}=0.884)$. Milan기준을 이용한 생존율 분석에서 뇌사자간이식에서는 3년 생존율이 Milan기준에 부합되는
경우 $89.9 \%$ 및 벗어나는 경우 $66.4 \%$ 였고, 생체간이식에서는 각각 $91.4 \%$ 및 $62.6 \%$ 여서 별다른 차이를 보이지 않았다. 서 울아산병원에서 간세포암으로 생체간이식을 시행받은 환자 들의 결과에서도 Milan기준에 부합되는 환자들의 5년 생존 율이 $76.0 \%$ 를 보임으로써 뇌사자 간이식을 대상으로 한 연 구들과 동일한 결과를 보였다. ${ }^{6}$ 따라서 기증자의 수술 위험 에 대한 충분한 고려가 이루어진다면 뇌사자간이식에 적용 되어왔던 대상자 선정기준이 생체간이식에 그대로 적용되 더라도 동일한 치료 결과를 기대할 수 있다고 판단된다. ${ }^{23}$ 또한 뇌사 공여자의 수가 절대적으로 부족한 국내 현실을 고려할 때 생체간이식이 간경변을 동반한 간세포암의 치료 에 있어 보다 더 적합한 치료법이 될 수 있을 것이다.

\section{간세포암 환자에서 간이식 대상자 선정기준}

\section{Milan기준 및 확대 기준}

간세포암에서 이식대상 선정기준은 뇌사자간이식에서는 공공 자산의 효율적인 이용이라는 측면이 강조되고 생체간 이식에서는 기증자 수술 위험의 정당화라는 측면에서 그 의

Table 2. Comparison of Data and Outcomes of the HCC Patients Who Underwent Deceased-donor and Living-donor Liver Transplantations (DDLT and LDLT) at 4 Centers of Korea from August 1992 to December $2002^{22}$

\begin{tabular}{|c|c|c|c|}
\hline Parameter & DDLT & LDLT & $\mathrm{p}$-value \\
\hline Number of patients & $75(24 \%)$ & $237(76 \%)$ & \\
\hline Age (years, mean $\pm \mathrm{SD}$ ) & $49 \pm 7$ & $50 \pm 8$ & 0.599 \\
\hline Sex, n (\%) & & & 0.595 \\
\hline Male & $60(79.0)$ & $196(82.7)$ & \\
\hline Female & $15(21.0)$ & $41(17.3)$ & \\
\hline Serology, n (\%) & & & 0.458 \\
\hline Hepatitis B & $68(90.7)$ & $215(90.7)$ & \\
\hline Hepatitis C & $6(8.0)$ & $13(5.5)$ & \\
\hline Hepatitis $\mathrm{B}$ and $\mathrm{C}$ & 0 & $8(3.4)$ & \\
\hline None & $1(1.3)$ & $1(0.4)$ & \\
\hline Child-Pugh classification, $\mathrm{n}(\%)$ & & & 0.005 \\
\hline Class A & $4(5.3)$ & $29(12.2)$ & \\
\hline Class B & $13(17.3)$ & $70(29.5)$ & \\
\hline Class C & $55(73.4)$ & $138(58.3)$ & \\
\hline Pathologic tumor staging, $\mathrm{n}(\%)$ & & & 0.767 \\
\hline $\mathrm{T} 1$ & $34(45.3)$ & $116(49.0)$ & \\
\hline $\mathrm{T} 2$ & $25(33.3)$ & $96(40.5)$ & \\
\hline $\mathrm{T} 3$ & $16(21.3)$ & $25(10.5)$ & \\
\hline $\mathrm{T} 4$ & 0 & 0 & \\
\hline Milan criteria & & & 0.694 \\
\hline Within & $53(70.7)$ & $173(73.0)$ & \\
\hline Beyond & $22(29.3)$ & $64(27.0)$ & \\
\hline Perioperative mortality, n (\%) & $14(18.7)$ & $24(10.1)$ & 0.048 \\
\hline Overall 3-year survival rate $(\%)$ & 61.3 & 73.2 & 0.043 \\
\hline 2-year recurrence-free survival rate $(\%)$ & 81.6 & 79.7 & 0.884 \\
\hline
\end{tabular}


미를 가진다고 할 수 있다. 간이식 대상자 선정의 표준 기준 으로 여겨지고 있는 Milan기준은 치료 효과라는 측면에서는 만족할 만한 성과를 달성했지만 치료 혜택의 기회를 엄격히 제한했다는 측면에서는 지속적인 비판을 받아왔다. 따라서 Milan기준에 비해 수혜의 폭을 넓히면서도 동등한 치료결과 를 담보할 수 있는 새로운 기준에 대한 연구가 계속 진행되 어 왔으나 획기적인 해결책은 아직 제시되지 못한 실정이 다. Yao 등 24 은 Milan기준을 좀 더 확대하여 단일 결절에서 는 직경 $6.5 \mathrm{~cm}$ 미만, 다수의 결절에서는 개수가 3 개 이하이 면서 최대 직경이 $4.5 \mathrm{~cm}$ 이하이고 직경의 합이 $8 \mathrm{~cm}$ 이하 일 경우 1년 및 5년 생존율이 각각 $90 \%$ 및 $75 \%$ 로 Milan기 준과 대등한 결과를 보인다고 보고했고, 이 기준은 UCSF (University California San Francisco) 기준으로 불린다. 이후 연구들에서는 UCSF기준을 이식대상자 선정기준으로 적용 할 경우 이전의 Milan기준에 비해 10-20\% 정도 이식대상자
의 범위가 확대될 수 있는 것으로 보고하고 있다. ${ }^{25}$ 생체간 이식에서는 Milan기준이나 UCSF기준과 비교하여 보다 더 확대된 기준을 적용하고 있는데, Tokyo 대학팀은 소위 '5-5 rule'로 개수 5 개 이하 및 최대 직경 $5 \mathrm{~cm}$ 이하를 적절한 이 식 대상자로 규정하고 있으며, Kyoto 대학팀은 개수 10 개 이하 및 최대 직경 $5 \mathrm{~cm}$ 이하로 규정하고 있다. ${ }^{10}$

저자들은 1997년 2월부터 2004년 12월까지 787명이 성인 생체 간이식을 시행 받았는데, 이들 중 우연히 발견된 간세 포암과 간내담관암을 동반한 31 명을 제외한 221 명의 간세 포암 환자를 대상으로 재발률 및 생존율에 영향을 미치는 인자들을 분석하였다. 15 예의 조기사망 예를 제외한 206명 의 분석 결과, 종양의 최대 직경 $5 \mathrm{~cm}$ 이하, 개수가 6 개 이 하 및 주요혈관 침범이 없는 경우 현저히 낮은 재발률과 높 은 생존율을 보였는데, 이 기준은 '아산기준'으로 불리고 있 다(Table 3). ${ }^{6}$ 아산기준에 부합되는 경우 1년, 3 년 및 5년 재

Table 3. Risk Factors for Hepatocellular Carcinoma Recurrence and Patient Survival in 206 Patients Who Underwent Living-donor Liver Transplants from February 1997 to December 2004 at Asan Medical Center ${ }^{6}$

\begin{tabular}{|c|c|c|c|c|c|c|}
\hline \multirow{2}{*}{ Risk factors } & \multicolumn{3}{|c|}{ Hepatocellular carcinoma recurrence } & \multicolumn{3}{|c|}{ Patient survival } \\
\hline & Hazard ratio & $95 \% \mathrm{CI}$ & p-value & Hazard ratio & $95 \% \mathrm{CI}$ & p-value \\
\hline Largest tumor diameter $>5 \mathrm{~cm}$ & 6.08 & $2.720-13.59$ & $<0.001$ & 4.63 & $2.11-10.19$ & $<0.001$ \\
\hline Tumor number $>6$ & 6.65 & $3.02-14.63$ & $<0.001$ & 6.22 & $2.96-13.08$ & $<0.001$ \\
\hline Gross vascular invasion present & 2.53 & $1.39-6.28$ & 0.042 & 2.63 & $1.07-6.48$ & 0.035 \\
\hline
\end{tabular}

CI, confidence interval

A

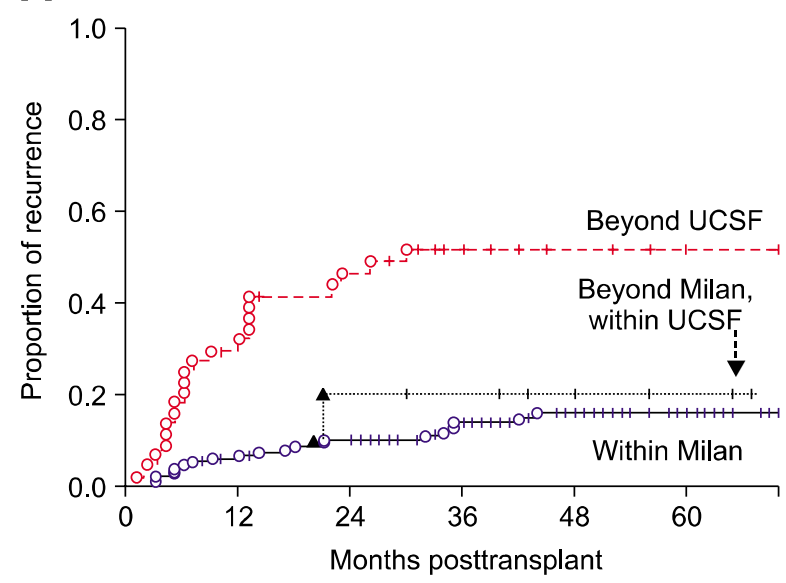

B

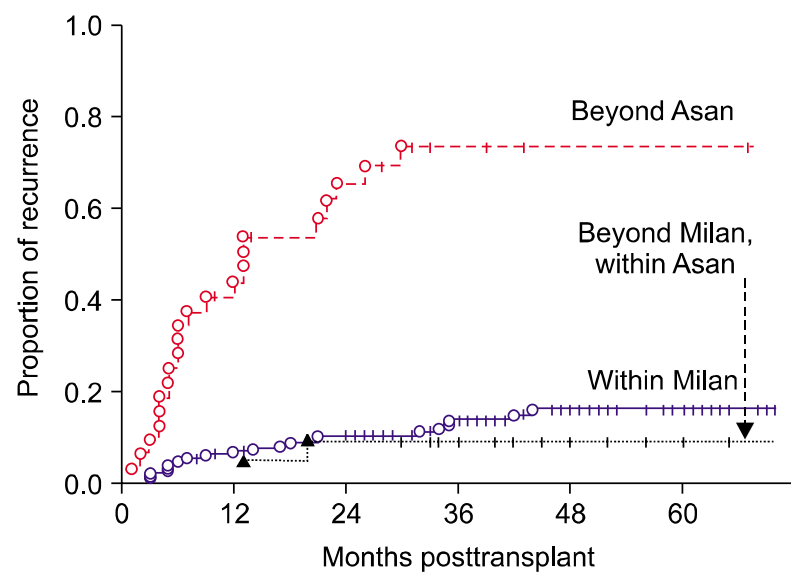

Fig. 3. Comparison of the hepatocellular carcinoma (HCC) recurrence curves of 206 patients who underwent living-donor liver transplantation from February 1997 to December 2004 at Asan Medical Center based on explant pathology. (A) HCC recurrence curves of the patients beyond the Milan criteria but within UCSF criteria showed 1-year, 3-year, and 5-year recurrence rates of 0\%, 20.0\%, and $20.0 \%$, respectively. There was no statistically significant difference in recurrence rates between the patient group beyond the Milan criteria but within the UCSF criteria and the patient group within the Milan criteria ( $\mathrm{p}=0.626)$. (B) HCC recurrence curves of the patients beyond the Milan criteria but within the Asan criteria showed 1-year, 3-year, and 5-year recurrence rates of 0\%, 9.1\%, and 9.1\%, respectively. There was no statistically significant recurrence difference between the patient group beyond the Milan criteria but within the Asan criteria and that within the Milan criteria $(\mathrm{p}=0.554){ }^{6}$ 
A

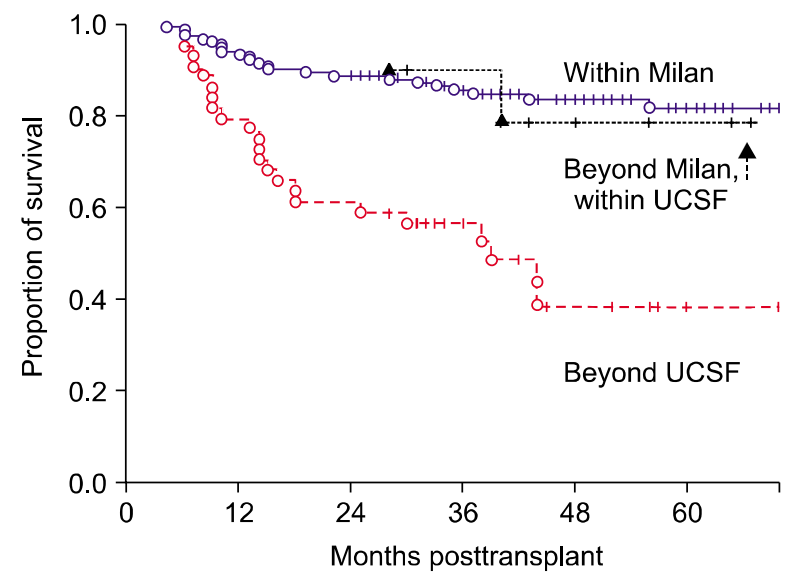

B

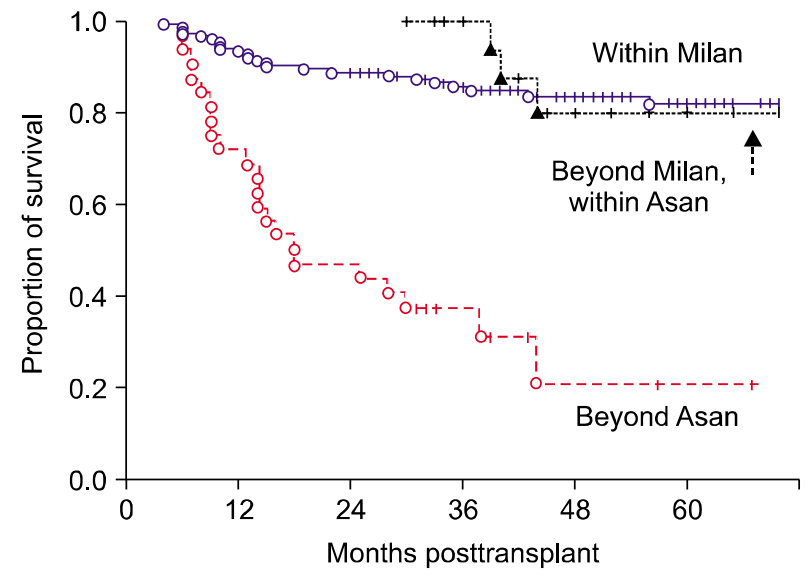

Fig. 4. Comparison of the patient survival curves of 206 patients who underwent living-donor liver transplantation from February 1997 to December 2004 at Asan Medical Center based on explant pathology. (A) Patient survival curves of the patients beyond the Milan criteria but within UCSF criteria showed 1-year, 3-year, and 5-year survival rates of $100 \%, 90.0 \%$, and $78.8 \%$, respectively. There was no statistically significant difference in survival rates between the patient group beyond the Milan criteria but within the UCSF criteria and the patient group within the Milan criteria ( $\mathrm{p}=0.923)$. (B) Patient survival curves of patients beyond the Milan criteria but within the Asan criteria showed 1-year, 3-year, and 5-year recurrence rates of 100\%, 88.9\%, and 80.0\%, respectively. There was no statistically significant survival difference between the patient group beyond the Milan criteria but within the Asan criteria and that within the Milan criteria $(p=0.334)^{6}$

발률이 각각 $5.8 \%, 13.5 \%$ 및 $15.0 \%$ 였으며, 벗어나는 경우는 각각 $43.3 \%, 73.6 \%$ 및 $73.6 \%$ 였다(Fig. 3). 1년, 3년 및 5년 생 존율은 아산기준에 부합되는 경우 각각 $94.3 \%, 87.5 \%$ 및 $81.6 \%$ 였고, 벗어나는 경우에는 각각 $71.9 \%, 37.2 \%$ 및 $20.7 \%$ 였다(Fig. 4). 또한 이 연구 대상자들을 각각 Milan기준, $\mathrm{UCSF}$ 기준 및 아산기준으로 각각 재발률과 생존율을 교차 비교해 보았을 때 재발률 및 생존율에 있어 모두 유사한 결 과를 보였으나, 수혜자 범위 확대라는 측면에서 아산기준은 Milan기준에 비해 $10.5 \%, \mathrm{UCSF}$ 기준에 비해 $4.5 \%$ 의 확대효 과가 있는 것으로 평가되었다. 국내에서 서울대병원의 경우 개수 10 개 이하, 최대직경 $5 \mathrm{~cm}$ 이하 및 protein induced by vitamin $\mathrm{K}$ absence or antagonist-II (PIVKA-II) $400 \mathrm{mAU} / \mathrm{mL}$ 로 제한하고 있으며, ${ }^{8}$ 삼성서울병원의 경우 개수와는 상관 없 이 직경 $5 \mathrm{~cm}$ 이하 및 alpha-fetoprotein (AFP) $400 \mathrm{ng} / \mathrm{mL}$ 이 하로 제한하고 있다. ${ }^{9}$

앞서 예시한 다양한 확대기준들은 대부분 Milan기준을 적 용했을 때와 유사한 성적을 보고하고 있으며, 또한 선정 범 위가 5-54\%까지 확대되는 것으로 보고하고 있다. ${ }^{26}$ 그러나 대부분의 확대기준들은 개별 센터에서의 경험 및 자료만을 토대로 만들어져 객관적인 검증을 거치지 않은 단계여서 대 개 해당 센터에서만 주로 사용되고 있는 것이 현실이다.

\section{2. 간이식 대상자 선정기준의 실제적용}

앞서 소개한 선정 기준은 이식수술 후 예후를 예측하기 위한 기준일 뿐 실제 이식 여부를 엄격히 제한하는 규정적
인 의미의 기준은 아니다. 물론 서구 여러 나라에서는 지역 에서는 뇌사자간이식의 적용에 있어 Milan기준을 벗어나는 환자들에게는 뇌사 공여장기의 할당을 제한하고 있으나, 국 내에서는 간세포암의 진전 정도와 관련한 규정 제한이 미미 하기 때문에 공여장기의 이식 여부는 해당 의료진의 판단에 맡기고 있다. 또한 생체간이식의 경우 앞서 예시한 기준들 에 따라 수술 여부를 엄격히 제한하기보다는 환자의 의학적 상황과 기증자의 기증 의사의 적극성 정도를 참고하여 보다 유연하게 기준을 적용하고 있는 현실이다. 이와 관련하여 통상의 기준을 넘어서는 진행성 간세포암에서 치료 효과의 확실한 근거가 부족한 상태에서 환자의 요구와 기증자의 자 발성에만 기인한 간이식의 결정에 대해 비판적인 의견도 있 다. 기증자 사망률이 $0.15-1.0 \%$ 이고 ${ }^{27}$ 합병증 발생률이 $5-66 \%$ 로 $^{28-30}$ 기증자의 수술 위험도가 실제로 존재하기 때문 에, 적어도 환자의 이식 후 장기 생존율이 $50 \%$ 이상 되는 경우에만 수술이 허용되어야 한다는 주장도 있다. ${ }^{31}$ 반면 간 이식 이외에는 치료의 기회를 가질 수 없는 간세포암 환자 에서 기증자의 자발적인 동기에 의한 적극적 기증 의사가 있는 경우에도 단지 의학적인 기준에 의해 개인의 치료의 선택권을 제한하는 것 또한 윤리적인 문제가 있다는 지적도 있다. 따라서 실제 의료 현장에서는 선정기준을 벗어난 진 행성 간세포암 환자의 간이식 수술 결정에 있어 의학적인 결정과 환자의 요구가 상충되는 곤란한 경우가 종종 일어난 다. 이런 경우 의료진 측에서는 생체간이식 공여자의 조건 (연령, 기저 간기능, 예상 잔존 간용적, 전신상태 등)에 대한 
면밀한 검토와 수술 위험도에 대한 정밀한 재평가를 시행 후 공여자에게 이를 충분히 이해시키고 고지해야 한다. 또 한 환자의 간세포암 진행 정도를 정확하게 평가하여 재발 가능성을 예측하고 환자 및 공여자 모두에게 이식 후 재발 가능성이 높다는 점과 조기 재발의 가능성이 있다는 점, 그 리고 재발 후 급속한 암의 진행과 불량한 예후에 대해 알려 야 한다. 앞선 내용을 공여자와 환자 모두가 충분히 이해했 는지를 평가 후 환자의 치료 의지나 공여자의 자발적인 기 증의사에 변함이 없다면 간세포암의 진행 정도가 통상적인 선정 기준을 넘어선다 하더라도 사안별로 간이식 수술을 시 행할 수 있을 것으로 판단된다. 저자들도 아산기준을 벗어 나는 환자들에서도 사안별로 신중하게 간이식 수술을 시행 하고 있으나, 간외 전이가 있거나 간문맥, 간정맥 등과 같은 주요 혈관 침습이 분명한 경우에는 철저하게 간이식 수술을 제한하고 있다.

\section{3. 생물학적 지표를 이용한 새로운 선정기준}

간세포암 환자의 예후와 관련된 여러 인자들이 보고되어 왔지만 근원적으로는 모든 악성종양의 경과는 종양의 생물 학적인 특성에 의해 결정된다. 종양의 악성 정도 및 침습성 에 따라 환자의 예후가 결정되며 예후 인자로 알려진 몇몇 지표들은 이런 종양의 악성 정도 및 침습성을 간접적으로 반영할 것이다. 현재까지는 이런 지표들 중 종양의 개수, 크 기 및 혈관 침범 여부가 종양의 생물학적인 특성과 가장 밀 접한 관련이 있는 간접적 지표로 알려져 있으며, 대부분의 선정 기준은 이 세 가지 요소를 조합하여 만들어졌다. ${ }^{411}$

이와는 달리 수술 전 종양을 직접 생검하여 종양의 분화 도 및 조직학적인 특성을 파악하는 것이 이식 후 재발 위험 도를 평가하는 데 더 정확한 정보를 준다는 주장도 있으 나, ${ }^{32,33}$ 대규모 연구를 통한 검증이 이루어지지 못했으며, 또 한 이식 전 생검의 경우 기저 간기능이 불량한 환자에서 심 각한 합병증을 유발할 가능성이 있고, 생검 과정 중 간세포 암의 복막 파종 및 간내 전이를 유발할 위험이 있어 생검의 임상적용은 매우 제한적이다. ${ }^{34,35}$ 따라서 현재까지 대부분의 연구들은 환자의 혈액에서 유래한 표지인자들을 대상으로 활발히 이루어져 왔으며, 이들 중 AFP 및 PIVKA-II가 가장 주목을 받아온 표지인자들이다. ${ }^{36-38}$ 여러 연구들을 통해 어 느 정도 재발률과의 연관성이 입증되었으나 검사의 특이도 및 변별력을 결정하는 임계값에 대한 통일된 기준이 없고 선정 기준이 모호하다는 문제가 남아 있다.

최근 기능적 영상 진단법의 발전으로 인해 간세포암의 생 물학적인 활성도를 수술 전에 미리 판단할 수 있는 방법들 이 연구되고 있다. 그 중 18-fluorodeoxyglucose positron emission tomography (18-FDG PET)의 유용성이 주목을 받고 있다. ${ }^{39}$ 국내에서는 Yang 등 ㄴ,41이 PET 양성인 경우가 음성인 경우

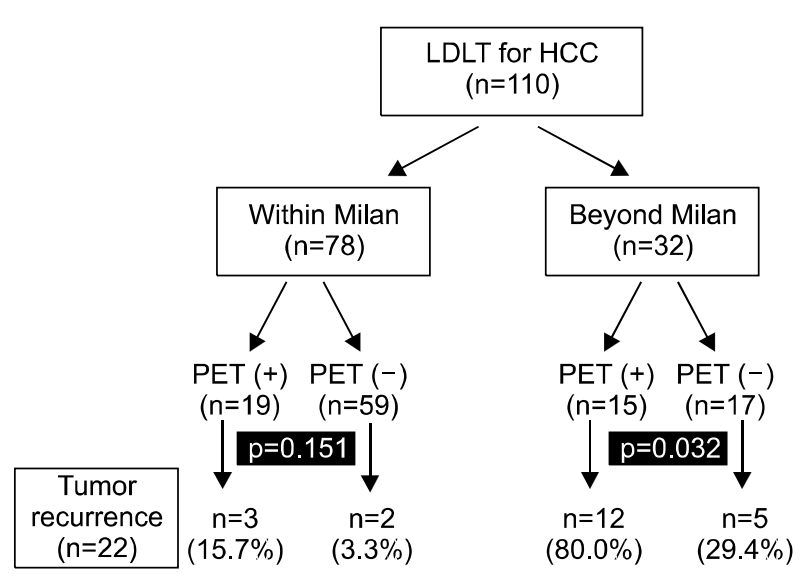

Fig. 5. Recurrence of hepatocellular carcinoma in recipients having positive positron emission tomography (PET) scans. LDLT, living-donor liver transplantation.

에 비해 예후가 불량하며 $\mathrm{AFP}$ 수치와 함께 적용할 경우 예 후가 불량할 것으로 예측되는 환자군을 선정하는데 도움이 되는 것으로 보고하였다. 저자들도 2003년 1월부터 2005년 12 월까지 간세포암으로 생체간이식을 받은 110 명의 환자를 대상으로 재발률의 예측 시 PET의 유용성을 평가했다(Fig. 5). 그 결과 Milan기준에 부합되는 78명의 환자에서 PET음성인 경우 2년 재발률이 $3.3 \%$ 에 불과했으나, PET양성인 경우에 는 $15.7 \%$ 로 유의하게 높았다. Milan기준을 벗어나는 32 명의 환자에서도 PET양성인 경우가 음성인 경우에 비해 현저하 게 재발률이 높은 것으로 평가되었다. 따라서 PET는 기존의 간세포암의 간이식 대상자 선정기준에 사용되어왔던 종양 의 개수, 크기와 더불어 좋은 보조 표지인자로 사용될 수 있 을 것으로 판단된다.

저자들은 최근 분석에서 기존의 아산기준에 더하여 종양 의 크기 $5 \mathrm{~cm}$ 이상, 수술 전 $\mathrm{AFP}>1,000 \mathrm{ng} / \mathrm{dL}$, 수술 전 PET양성 및 수술 전 생검상 미분화암이라는 4 가지 위험인 자들 중 3 가지 이상의 조건에 해당될 경우 1 년 내 조기 재 발률이 $80 \%$ 를 상회한다는 분석결과를 얻었다.

한편 기존의 지표들이 어느 정도 검증된 예후 예측능을 보여주고 있으나 보다 직접적이고 정확하게 암종의 생물학 적인 특성을 반영할 수 있는 지표가 필요하다. 따라서 최근 분자생물학의 급속한 발전으로 인해 간세포암 연구에 있어 서도 DNA microarray기법 및 polymerase chain reaction을 이 용한 간세포암 관련 유전자에 대한 연구가 활발히 이루어지 고 있기 때문에 진단 및 예후 예측에 있어 획기적인 지표의 발견을 기대하고 있다. ${ }^{42,43}$ 또한 진단 뿐만 아니라 치료에 있어서도 수술 전 종양의 진행을 억제하고 수술 후 재발을 줄일 수 있는 유전자 표적치료제의 개발도 기대를 모으고 있다. 


\section{간이식 전 간세포암의 치료 및 down-staging}

간이식을 대기하고 있는 환자에서 이식 전 간세포암에 대 한 경동맥화학색전술 및 고주파열응고술 등의 국소치료는 흔히 시행되고 있는 치료법이다. ${ }^{44}$ 특히 뇌사자간이식의 경 우 긴 대기시간 동안 종양의 진행을 억제한다는 의미에서 이식 전 간세포암의 치료는 중요한 임상적인 의미를 가진 다. 또한 통상적인 선정기준을 벗어나는 진행성 간세포암 환자에서는 수술 전 치료로써 간세포암의 범위를 줄여 선정 기준에 부합되도록 만드는 소위 'down-staging'의 역할 또한 기대되는 부분이다. Yao 등 ${ }^{45}$ 은 UCSF기준을 벗어난 61 명의 환자들을 대상으로 한 연구에서 약 70\%에서 down-staging을 위한 이식 전 치료가 가능했으며, 이 중 약 $57 \%$ 가 성공적으 로 간이식을 시행 받을 수 있었다는 고무적인 결과를 보고 하였다. 그러나 Yao 등의 연구에서 대상이 되었던 환자들은 대부분 UCSF기준을 벗어나지만 생체간이식에서 적용되고 있는 여러 기준들에는 대부분 부합되는 환자들을 대상으로 한 연구라는 맹점을 가지고 있어, 그들의 연구 결과를 downstaging의 임상적인 효과를 뒷받침하는 결과로 받아들이기 에는 무리가 있다. 또한 이후 대부분의 연구들에서는 downstaging의 만족할 만한 결과를 보여주고 있지 못하다. ${ }^{46,47}$ 따 라서 down-staging을 위한 이식 전 치료는 치료적인 의미보 다는 치료에 대한 반응을 일정 기간 동안 평가하여 반응이 좋은 환자들에서 이식을 시행함으로써 예후가 양호할 수밖 에 없는 대상자를 선택하게 되는 '선택 효과(selection effectiveness)'의 의미가 더 큰 것으로 평가할 수 있다. ${ }^{48,49}$

간세포암의 이식 전 치료에서 수술적인 절제 또한 선택 가능한 방법 중의 하나이다. ${ }^{50-52}$ 이식 전 수술적인 절제가 가지는 의미는 외과적인 절제로 근치적인 치료를 시도하고 간이식은 이후 간기능의 악화나 간세포암의 재발시점으로 미뤄두는 구제요법(salvage treatment)으로서의 의미, 당장 기 증자의 부재로 생체간이식 혹은 뇌사자간이식을 시행할 만 한 조건이 되지 않는 경우 교량요법(bridge treatment)으로서 의 의미와 절제 후 조직학적인 검사를 통해 수술 전 영상검 사보다 더 정확한 종양의 범위 및 진행 정도를 파악할 수 있고 조직학적인 특성이 불량한 환자들은 일정 기간 관찰 후 조기 재발 등의 이유로 이식 대상자에서 제외하는 여과 요법(filtration effect)으로서의 의미를 가질 수 있다. 이식 전 간절제술이 수술로 인한 해부학적인 구조의 파괴와 복강 내 유착 등으로 인해 이후 간이식 수술의 기술적인 난이도를 높여 이식수술을 불가능하게 하거나 이식 후 수술합병증의 발생을 높일 수 있다는 우려도 있으나, ${ }^{50}$ 최근 보고들에 따 르면 기존의 우려와는 달리 수술적 환경이 이식 전 비수술 적인 치료를 받은 환자들과 크게 다르지 않고 수술 후 합병 증 발생률 또한 크게 다르지 않은 것으로 보고되고 있다. ${ }^{51,52}$
다만 절제를 시행 받은 환자의 이식 가능 여부에 대한 판단 기준과 적절한 이식 시점에 대해서는 통일된 기준이 마련되 어 있지 않아 후속적인 다기관 연구가 필요하다.

\section{간이식 후 간세포암의 재발 및 치료}

간이식 후 간세포암의 재발 양상은 수술적인 절제 시와는 다른 양상을 보인다. 수술적인 절제 후에는 주로 국소 재발 이 흔한 반면, 간이식 후에는 혈행성 파급을 통한 간외 재발 이 더 흔히 나타난다. ${ }^{53}$ 주로 폐와 뼈가 주된 재발 병소이다. 간이식 후 재발된 간세포암은 대부분 진행경과가 빠르며 예 후가 매우 불량하다. ${ }^{54}$ 명확한 이유가 아직까지는 밝혀져 있 지 않으나 이식 전 간세포암의 생물학적인 특성에 기인한 면도 있고, 이식 후 투여된 면역억제제가 환자의 암 감시기 능을 저하시킨 점도 영향이 있을 것으로 추정된다. 이식 후 재발까지의 기간은 평균 4.5-12.3개월이며 재발 후 평균 생 존 기간은 6.1-12.0개월인 것으로 보고되고 있다.55-58 이식 후 재발 시점까지의 기간이 긴 경우, 수술적인 절제가 가능 한 재발 병소인 경우에는 재발 후 생존기간이 비교적 길지 만, 거의 대부분의 환자가 결국 암 전이로 사망하였다. 55,58 암재발 후 치료방법은 재발 위치와 범위에 따라 사안별로 결정되는데 재발 병소가 이식편 내에 국한된 경우에는 대부 분 경동맥화학색전술이나 고주파열응고술을 시도하게 된 다. 전간 뇌사자간이식 후에서는 경우에 따라 수술적인 절 제도 시도할 수 있다. 폐전이에 대해서는 단발성이거나 다 발성이라도 그 위치가 국소적으로 집중된 경우 수술적 절제 를 시도할 수 있으며, 최근 들어서는 향강경을 이용한 최소 침습수술이 주로 시도되고 있다. 골전이에 대해서는 통증 조절 목적으로 주로 체외방사선조사법을 시행한다. 수술적 인 절제가 불가능하거나 국소요법의 적용이 불가능한 병소 인 경우 전신적인 항암요법을 시도할 수 있으나, 아직 효과 적인 항암요법이 정립되지 않았으며 주목할 만한 결과를 보 여주지도 못하고 있는 실정이다..$^{59}$ 또한 면역결핍 상태의 환 자에서 전신항암요법이 패혈성 합병증을 일으킬 위험이 높 고 바이러스성 간염의 재발을 촉진한다는 점에서도 적용의 어려움이 있다. 또한 간세포암의 재발은 암세포 내에서도 B 형간염 바이러스의 증식을 동시에 촉진하는 것으로 알려져 있기 때문에 강력한 B형간염 예방요법을 시행해야 한다. 따 라서 B형간염글로불린 단독요법을 받고 있는 환자에서는 항바이러스제를 추가해야 한다.

간이식 후 면역 억제제의 사용은 간세포암의 재발과 어느 정도 관련이 있는 것으로 알려져 있다. 간이식 후 면역 억제 요법의 근간이 되는 calcineurin억제제의 경우 동물실험 및 인체 실험에서 모두 transforming growth factor-beta (TGF- $\beta$ ), vascular endothelial growth factor (VEGF), interleukin-6 (IL-6) 
등과 같은 암성장 촉진인자들의 생성을 유발시키는 것으로 알려져 있다. ${ }^{60,61}$ 임상연구에서도 고농도의 calcineurin억제제 에 노출된 환자군에서 간세포암의 재발률이 더 높은 것으로 보고되기도 하였다. 스테로이드의 경우 고용량의 충격요법 이나 장기간의 사용이 간세포암의 재발을 촉진하는 것으로 알려져 있다. 면역 유도 요법으로 OKT-3, anti-lymphocyte globulin (ALG) 및 anti-thymocyte globulin (ATG)는 간세포암의 재발을 촉진하는 것으로 알려져 있으나, interleukin-2 receptor antagonist에 대해서는 아직 알려진 바가 거의 없다. 최근 새 로운 세대의 면역억제제로 주목을 받고 있는 mammalian target of rapamycin (mTOR) 제제의 경우 항암효과가 있는 것으로 알려져 간세포암 환자의 이식 후 주요 면역억제제로 이용되거나 재발 후 치료제로 시도되고 있으나 안전성 및 유용성이 아직은 입증되지 않았다. ${ }^{62,63}$

\section{결 론}

수술적인 절제가 불가능한 간세포암에서 간이식은 효과 적인 치료법이 될 수 있다. 그러나 제한된 뇌사공여자의 숫 자 및 생체기증자의 수술 위험도를 고려할 때, 이식 후 만족 할 만한 결과를 담보하고 동시에 종양 진전 범위가 지나치 게 제한되지 않는 가장 합리적인 대상자 선정기준이 마련되 어야 한다. 향후 새로운 면역억제제의 도입과 유전자 기법 을 이용한 진단 및 치료기법이 뒷받침된다면 간세포암 환자 에서의 간이식은 보다 넓은 적용기준을 가지고 향상된 치료 성적을 보일 수 있을 것으로 기대된다.

\section{참고문헌}

1. van der Putten AB, Bijleveld CM, Slooff MJ, Wesenhagen $H$, Gips $\mathrm{CH}$. Selection criteria and decisions in 375 patients with liver disease, considered for liver transplantation during 19771985. Liver 1987;7:84-90.

2. O'Grady JG, Polson RJ, Rolles K, Calne RY, Williams R. Liver transplantation for malignant disease. Results in 93 consecutive patients. Ann Surg 1988;207:373-379.

3. Bismuth H, Chiche L, Adam R, Castaing D, Diamond T, Dennison A. Liver resection versus transplantation for hepatocellular carcinoma in cirrhotic patients. Ann Surg 1993; 218:145-151.

4. Mazzaferro V, Regalia E, Doci R, et al. Liver transplantation for the treatment of small hepatocellular carcinomas in patients with cirrhosis. N Engl J Med 1996;334:693-699.

5. Yao FY, Ferrell L, Bass NM, Bacchetti P, Ascher NL, Roberts JP. Liver transplantation for hepatocellular carcinoma: comparison of the proposed UCSF criteria with the Milan criteria and the Pittsburgh modified TNM criteria. Liver Trasnpl 2002;8:765-774.

6. Lee SG, Hwang S, Moon DB, et al. Expanded indication criteria of living donor liver transplantation for hepatocellular carcinoma at one large-volume center. Liver Transpl 2008;14: 935-945.

7. Kwon CH, Kim DJ, Han YS, et al. HCC in living donor liver transplantation: can we expand the Milan criteria? Dig Dis 2007;25:313-319.

8. Suh KS, Cho EH, Lee HW, Shin WY, Yi NJ, Lee KU. Liver trnasplantation for hepatocellular carcinoma in patients who do not meet Milan criteria. Dig Dis 2007;25:329-333.

9. Ito T, Takada Y, Ueda M, et al. Expansion of selection criteria for patients with hepatocellular carcinoma in living donor liver transplantation. Liver Transpl 2007;13:1637-1644.

10. Sugawara Y, Tamura S, Makuuchi M. Living donor liver transplantation for hepatocellular carcinoma: Tokyo University series. Dig Dis 2007;25:310-312.

11. Soejima Y, Taketomi A, Yoshizumi T, et al. Extended indication for living donor liver transplantation in patients with hepatocellular carcinoma. Transplantation 2007;83:893-899.

12. Lee SG, Ahn CS, Ha TY, et al. Liver transplantation for hepatocellular carcinoma: Korean experience. J Hepatobiliary Pancreat Surg 2009 [Epub ahead of print].

13. Moon DB, Lee SG. Liver transplantation. Gut and liver 2009;3:145-165.

14. Moon DB, Lee SG, Hwang S. Liver transplantation for hepatocellular carcinoma: single nodule with Child-Pugh class A sized less than $3 \mathrm{~cm}$. Dig Dis 2007;25:320-328.

15. Gondolesi GE, Roayaie S, Munoz L, et al. Adult living donor liver transplantation for patient hepatocellular carcinoma: extending UNOS priority criteria. Ann Surg 2004;239:142-149.

16. Lo CM, Fan ST, Liu CL, Chan SC, Wong J. The role and limitation of living donor liver transplantation. Liver Transpl 2004;10:440-447.

17. Lo CM, Fan ST, Liu CL, Chan SC, Ng IO, Wong J. Living donor versus deceased donor liver transplantation for early irresectable hepatocellular carcinoma. Br J Surg 2007;94:78-86.

18. Hiatt JR, Carmody IC, Busuttil RW. Should we expand the criteria for hepatocellular carcinoma with living donor liver transplantation? -no, never. J Hepatol 2005;43:573-577.

19. Marcos A, Fisher RA, Ham JM, et al. Liver regeneration and function in donor and recipient after right lobe adult to adult living donor liver transplantation. Transplantation 2000;69: 1375-1379.

20. Drixler TA, Vogten MJ, Ritchie ED, et al. Liver regeneration 
is anangiogenesis-associated phenomenon. Ann Surg 2002; 236:703-712.

21. Todo S, Furukawa H: The Japanese Study Group on Organ Transplantation. Living donor liver transplantation for adult patients with hepatocellular carcinoma: experience in Japan. Ann Surg 2004;240:451-459.

22. Hwang S, Lee SG, Joh JW, Suh KS, Kim DG. Liver transplantation for adult patients with hepatocellular carcinoma in Korea: comparison between cadaveric donor and living donor liver transplantations. Liver Transpl 2005;11:1265-1272.

23. Hwang S, Lee SG, Belghiti J. Liver transplantation for HCC: its role. Eastern and western perspectives. J Hepatobiliary Pancreat Surg 2009 (Epub ahead of print)

24. Yao FY, Ferrel L, Bass NM, et al. Liver transplantation for hepatocellular carcinoma: expansion of the tumor size limits does not adversely impact survival. Hepatology 2001;33:13941403.

25. Yao FY, Bass NM, Nikolai B, et al. Liver transplantation for hepatocellular carcinoma: analysis of survival according to the intention-to-treat principle and dropout from waiting list. Liver Transpl 2002;8:873-883.

26. Furukawa $\mathrm{H}$, Shimamura $\mathrm{T}$, Suzuki $\mathrm{T}$, et al. Liver transplantation for hepatocellular carcinoma: the Japanese experience. J Hepatobiliary Pancreat Surg 2009 [Epub ahead of print].

27. Trotter JF, Adam R, Lo CM, Kenison J. Documented deaths of hepatic lobe donors for living donor liver transplantation. Liver Transpl 2006;12:1485-1488.

28. Lo CM, Fan ST, Liu CL, et al. Lessons learned from one hundred right lobe living donor liver transplants. Ann Surg 2004;240:151-158.

29. Hwang S, Lee SG, Lee YJ, et al. Lessons learned from 1,000 living donor liver transplantations in a single center: how to make living donations safe. Liver Transpl 2006;12:920-927.

30. Marsh JW, Gray E, Ness R, Starzl TE. Complications of right lobe living donor liver transplantation. J Hepatol 2009; 51:715-724.

31. Bruix J, Fuster J, Llovet JM. Liver transplantation for heptocellular carcinoma: foucault pendulum versus evidence-based decision. Liver Transpl 2003;9:700-702.

32. Cillo U, Vitale A, Bassanello M, et al. Liver transplantation for the treatment for moderately and well-differentiated hepatocellular carcinoma. Ann Surg 2004;239:150-159.

33. Marshall AE, Rushbrook SM, Voeler SL, et al. Tumor recurrence following liver transplantation for hepatocellular carcinoma: role of tumor proliferation status. Liver Transpl 2010; 16:279-288.
34. Durand F, Regimbeau JM, Belghiti J, et al. Assessment of the benefits and risks of percutaneous biopsy before surgical resection of hepatocellular carcinoma. J Hepatol 2001;35:254258.

35. Perkins JD. Seeding risk following percutaneous approach to hepatocellular carcinoma. Liver Transpl 2007;13:1603-1607.

36. Han K, Tzimas GN, Barkun JS, et al. Preoperative alpha-fetoprotein slope is predictive of hepatocellular carcinoma recurrence after liver transplantation. Can J Gastroenterol 2007; 21:39-45.

37. Nanashima A, Morino S, Yamaguchi H, et al. Modified CLIP using PIVKA-II for evaluating prognosis after hepatoctomy for hepatocellular carcinoma. Eur J Surg Oncol 2003;29:735742.

38. Taketomi A, Sanefuji K, Soejima Y, et al. Impact of desgamma-carboxy prothrombin and tumor size on the recurrence of hepatocellular carcinoma after living donor liver transplantation. Transplantation 2009;87:531-537.

39. Hatano E, Ikai I, Higashi T, et al. Preoperative positron emission tomography with fluorine-18-fluorodeoxyglucose is predictive of prognosis in patients with hepatocellular carcinoma after resection. World J Surg 2006;30:1736-1741.

40. Yang SH, Suh KS, Lee HW, et al. The role of (18)F-FDGPET imaging for the selection of liver transplantation candidates among hepatocellular carcinoma patients. Liver Transpl 2006;12:1655-1660.

41. Yang SH, Suh KS, Lee HW, et al. A revised scoring system utilizing serum alphafetoprotein level to expand candidates for living donor liver transplantation in hepatocellular carcinoma. Surgery 2007;141:598-609.

42. Voulgari A, Pintzas A. Epithelial-mesenchymal transition in cancer metastasis: mechanisms, markers and strategies to overcome drug resistance in the clinic. Biochim Biophys Acta 2009; 1796:75-90.

43. Lee JS, Chu IS, Heo J, et al. Classification and prediction of survival in hepatocellular carcinoma by gene expression profiling. Hepatology 2004;40:667-676.

44. Lubienski A. Hepatocellular carcinoma: interventional bridging to liver transplantation. Transplantation 2005;80(suppl 1): S113-S119.

45. Yao FY, Kerlan RK Jr, Hirose R, et al. Excellent outcome following down-staging of hepatocellular carcinoma prior to liver transplantation: an intention-to-treat analysis. Hepatology 2008;48:819-827.

46. Soderdahl G, Backman L, Isoniemi $\mathrm{H}$, et al. A prospective, randomized, multi-centre trial of systemic adjuvant chemotherapy versus no additional treatment in liver transplantation 
for hepatocellular carcinoma. Transpl Int 2006;19:288-294.

47. Porrett PM, Peterman H, Rosen M, et al. Lack of benefit of pretransplant locoregional hepatic therapy for hepatocellular cancer in the current MELD era. Liver Transpl 2006;12: 665-673.

48. Decaens T, Roudot-Thoraval F, Bresson-Hadni S, et al. Impact of pretransplantation transarterial chemoembolization on survival and recurrence after liver transplantation for hepatocellular carcinoma. Liver Transpl 2005;11:767-775.

49. Perez Saborido B, Meneu JC, Moreno E, et al. Is transarterial chemoembolization necessary before liver transplantation for hepatocellular carcinoma? Am J Surg 2005;190:383-387.

50. Adam R, Azoulay D, Castaing D, et al. Liver resection as a bridge to transplantation for hepatocellular carcinoma on cirrhosis: a reasonable strategy? Ann Surg 2003;238:508-519.

51. Belghiti J, Cortes A, Abdalla EK, et al. Resection prior to liver resection for hepatocellular carcinoma. Ann Surg 2003; 238:885-893.

52. Hwang S, Lee SG, Moon DB, et al. Salvage living donor liver transplantation after prior liver resection for hepatocellular carcinoma. Liver Transpl 2007;13:741-746.

53. Schlitt HJ, Neipp M, Weimann A, et al. Recurrence patterns of hepatocellular and fibrolamellar carcinoma aftre liver transplantation. J Clin Oncol 1999;17:324-331.

54. Yokoyama I, Carr B, Saitsu H, Iwatsuki S, Starzl TE. Accelerated growth rates of recurrent hepatocellular carcinoma after liver transplantation. Cancer 1991;68:2095-2100.

55. Kornberg A, Küpper B, Tannapfel A, et al. Long-term survival after recurrent hepatocellular carcinoma in liver transplant patients: clinical patterns and outcome variables. Eur $\mathbf{J}$
Surg Oncol 2010;36:275-280.

56. Taketomi A, Fukuhara T, Morita K, et al. Improved results of a surgical resection for the recurrence of hepatocellular carcinoma after living donor liver transplantation. Ann Surg Oncol 2010 [Epub ahead of print].

57. Valdivieso A, Bustamante J, Gastaca M, et al. Management of hepatocellular carcinoma recurrence after liver transplantation. Transplant Proc 2010;42:660-662.

58. Roayaie S, Schwarts JD, Sung MW, et al. Recurrence of hepatocellular carcinoma after liver transplant: patterns of prognosis. Liver Transpl 2004:10:534-540.

59. Lee JO, Kim DY, Lim JH, et al. Palliative chemotherapy for patients with recurrent hepatocellular carcinoma after liver transplantation. J Gastroenterol Hepatol 2009;24:800-805.

60. Vivarelli M, Cucchetti A, Piscaglia F, et al. Analysis of risk factors for tumor recurrence after liver transplantation for hepatocellular carcinoma: key role of immunosuppression. Liver Transpl 2005;11:497-503.

61. Vivarelli M, Cuccetti A, La Barba G, et al. Liver transplantation for hepatocellular carcinoma under calcineurin inhibitors: reassessment of risk factors for tumor recurrence. Ann Surg 2008;248:857-862.

62. Wang Z, Zhou J, Fan J, et al. Sirolimus inhibits the growth and metastatic progression of hepatocellular carcinoma. J Cancer Res Clin Oncol 2009;135:715-722.

63. Toso C, Meeberg GA, Bigam DL, et al. De novo sirolimusbased immunosuppression after liver transplantation for hepatocellular carcinoma: long-term outcomes and side effects. Transplantation 2007;83:1162-1168. 